100 Schrier, R. W., Verroust, P. J., Jones, J. J., Fabian, M., Lee, J., and de Wardener, H. E., Clinical Science, 1968, 35, 433.

101 Selkurt, E. E., and Post, R. S., American fournal of Physiology, 1950, 162, 639.

102 Slatopolsky, E., Elkan, I. O., Weerts, C., and Bricker, N. S., fournal of Clinical Investigation, 1968, 47, 521 .

${ }_{103}$ Smith, H. W., American fournal of Medicine, 1957, 23, 623.

${ }_{104}$ Solomon, S., fournal of Cellular and Comparative Physiology, 1957, 49,351 .

205 Sonnenberg, H., and Pearce, J. W., American fournal of Physiology, 1962, 203, 344 .

ion Stamler, J., Dreifus, L., Katz, L. N., and Lichton, I. J., American fournal of Physiology, 1958, 195, 362. 10 : Starling, E. H., and Verney, E. B., Proceedings of the Royal Society.

ins Stein, R. M., Bercovitch, D. D., and Levitt M. F., American fournal Stein, R. M., Bercovitch, D. D.,
of Physiology, 1964, 207, 826.

(11) Steinhausen, M., Pflugers Archiv fur die gesamte Physiologie des Menschen und der Tiere, 1963, 277, 23.

10 Steinhausen, M., Pflugers Archiv fur die gesamte Physiologie des Menschen und der Tiere, 1964, 279, 195

11 Strauss, M. B., Davis, R. K., Rosenbaum, J. D., and Rossmeisl, E. C. fournal of Clinical Investigation, 1952, 31, 80.

11. Strauss, M. B., and Earley, L. E., Transactions of the Association of American Physicians, 1959, 72, 200.

113 Thaysen, J. H., Lassen, N. A., and Munck, O., Nature, 1961, 190 919.

114 Thurau, K., Proceedings of the Society for Experimental Biology and Medicine, 1961, 106, 714.

115 Tisher, C. C., Bulger, R. E., and Trump, B. F., Laboratory Investigation, 1966, 15, 1357.

116 Tisher, C. C., and Cirksena, W. J., Sodium localisation by electron microscopy (E. M.) in single perfused renal tubules. Abstract, American Society of Nephrology 1968, Washington.
117 Tobian, L., Coffee, K., and McCrea, P., Transactions of the Association of American Physicians, 1967, 80, 200.

118 Ullrich, K. J., Rumrich, G., and Fuchs, G., Pflugers Archiv fur die gesamte Physiologie des Menschen und der Tiere, 1964, 280, 99.

119 Voute, C. L., Fournal of Ultrastructure Research, 1963, 9, 497.

120 Walker, A. M., Bott, P. A., Oliver, J., and MacDowell, M. C. American fournal of Physiology, 1941, 134, 580 .

121 Wardener, de H. E., Mills, I. H., Clapham, W. F., and Hayter, C. J., Clinical Science, 1961, 21, 249.

123 Welt, L. G., in Diseases of Metabolism, 5th ed., edited by G. G. Duncan, 1964, p. 486. Philadelphia, Saunders.

123 Wesson, L. G., Medicine, 1957, 36, 281.

125 Whittembury, G., Sugino, N., and Solomon, A. K., fournal of General Physiology, 1961, 44, 689.

126 Whittembury, G., and Windhager, E. E., fournal of General Physiology, 1961, 44, 679.

12: Wiederholt, M., Hierholzer, K., Windhager, E. E., and Giebisch, G., American fournal of Physiology, 1967, 213, 809.

13 Wiggins, W. S., Manry, C. H., Lyons, R. H., and Pitts, R. F. Circulation, 1951, 3, 275 .

1.9 Windhager, E. E., American fournal of Physiology, 1964, 206, 694.

130 Windhager, E. E., and Giebisch, G., American fournal of Physiology, $1961,200,581$.

131 Windhager, E. E., Lewy, J. E., and Spitzer, A., Nephron, 1969, 6,

247.
133 Wirz, F., Helvetica Physiologica et Pharmacologica Acta, 1956, 14, 353 ,

133 Wright, F. S., Brenner, B. M,. Bennett, C. M., Keimowitz, R. I. Berliner, R. W., Schrier, R. W.. Verroust, P. J., de Wardener, H. E., and Hoizgreve, H., fournal of Clinical Investigation, 1969, 48, 1107.

134 Wright, F. S., Knox, F. H., Howards, S. S., and Berliner, R. W. American fournal of Physiology, 1969, 216, 869 .

\title{
Triple Starr Valve Replacement
}

\author{
M. V. BRAIMBRIDGE,* M.A., M.B., F.R.C.S. ; A. J. CLEMENT, $†$ M.B., D.A., F.F.A. R.C.S. \\ A. HEDLEY BROWN, $\ddagger$ M.B., B.S., F.R.C.S. ; E. SABAR,§ M.D. ; D. MENDEL,\| M.B., B.S., M.R.C.P.
}

[With Special Plate between Pages 692-693]

British Medical fournal, 1969, 3, 683-688

\begin{abstract}
Cummary : Of nine patients who have had triple valve $S$ replacements for organic rheumatic triple valve disease two died in the postoperative period from inadequate myocardial reserve, and a third died four months later from cerebral embolism originating from clot on the left atrial wall. The remainder are well and, except for one, leading normal lives. Though cardiac transplantation has been recommended and used successfully for triple valve disease by Cooley, it is suggested that the long-term outlook today of triple valve replacement is likely to be better than that of transplantation.
\end{abstract}

\section{Introduction}

Culey et al. (1968) suggested that severe multiple valve disease due to rheumatic fever could be treated by transplantation of the heart and had performed one such operation. The risks and benefits of triple valve replacement, which is the alternative, have therefore to be compared with those of transplantation.

A single heart valve can be replaced today with an operative mortality of some $10-15 \%$, with deaths due mainly to pulmonary vascular or myocardial disease. The safety of triple valve replacement has not yet reached this stage. Experience

* Consultant Surgeon.

† Consultant Anaesthetist.

₹ Lecturer in Cardiac Surgery, Cardiothoracic Unit.

Consultant Physician, Cardiothoracic Unit.

St. Thomas's Hospital, London S.E.1.

Professor of Cardiothoracic Surgery, University of Erzurum, Turkey. is relatively small and the operative technique, postoperative management, and long-term results are still not uniform. The purpose of this paper is to report a personal series of nine triple valve replacements performed at St. Thomas's Hospital between July 1966 and May 1968, with an assessment of the risks involved and the functional results obtained.

Pathology.-Triple valve disease is always due to rheumatic fever (Special Plate, Fig. 1). Regurgitation was the dominant lesion in each valve of every patient in this series, though a significant degree of stenosis accompanied regurgitation in four mitral, two aortic, and five tricuspid valves. Four of the mitral and two of the aortic valves were calcified.

\section{Indications for Triple Valve Replacement}

Our minimum indication for operation is moderately severe dyspnoea with inability to walk at a good pace on the flat (grade $2 \mathrm{~b}$ on the Wood grading). Dysnnoea on exertion was severe in seven patients, gross in one, and moderately severe in one in this series (see Table). Dyspnoea was accompanied by orthopnoea in seven and by paroxysmal nocturnal dyspnoea in five patients. Angina pectoris was present in two patients, with effort syncope in one patient.

Each patient received intensive preliminary medical treatment before the final clinical examination and cardiac catheterization, and this was continued until no further improvement could be obtained. The jugular venous pressure, which was raised on admission in all patients, was reduced to normal by 
Details of Cases

\begin{tabular}{|c|c|c|c|c|c|c|c|c|}
\hline Case & Sex & Age & $\begin{array}{l}\text { Symp- } \\
\text { toms }\end{array}$ & Mitral Valve & Aortic Valve & Tricuspid Valve & $\begin{array}{c}\text { Pulmonary Vascular } \\
\text { Resistance }\end{array}$ & $\begin{array}{l}\text { Present } \\
\text { Condition }\end{array}$ \\
\hline 1 & $\mathbf{M}$ & 40 & \begin{tabular}{|c|} 
Grade 3 \\
dyspnoea \\
orthopnoea. \\
C.C.F.
\end{tabular} & $\begin{array}{l}\text { Clinically: grade } 3 \text { incom- } \\
\text { petence, with grade } 1 \\
\text { stenosis. Catheter: }\end{array}$ & $\begin{array}{l}\text { Clinically: grade } 2 \text { stenosis and } \\
\text { grade } 2 \text { incompetence. Cathe- } \\
\text { ter: No stenosis. Grade } 2 \\
\text { incompetence }\end{array}$ & $\begin{array}{l}\text { Clinically: grade } 2 \text { incompetence. } \\
\text { Catheter: No gradient across } \\
\text { valve. No murmurs in atrium }\end{array}$ & $\begin{array}{l}\text { R.V.P. } 50 / 0 \text {. } \\
\text { L.A.P. } 45 / 26 \text {. } \\
\text { Normal resistance }\end{array}$ & $\begin{array}{l}\text { Working full time } 2 \frac{1}{2} \\
\text { years after surgery. } \\
\text { C.T.R. reduced } \\
\text { from } 65 \text { to } 56 \%\end{array}$ \\
\hline 2 & $\mathbf{M}$ & 45 & $\begin{array}{c}10 \text { attacks } \\
\text { of } \\
\text { pulmonary } \\
\text { oedema. } \\
\text { Grade } 2 \mathrm{~b} \\
\text { dyspnoea }\end{array}$ & $\begin{array}{l}\text { Clinically: severe incom- } \\
\text { petence grade } 3 \text {. } \\
\text { Catheter: loud pansys- } \\
\text { tolic murmur in left } \\
\text { atrium. Angiogram: } \\
\text { severe (grade 3) incom- } \\
\text { petence }\end{array}$ & $\begin{array}{l}\text { Clinically: severe incompetence. } \\
\text { Catheter: long (grade } 3 / 4 \text { ) } \\
\text { aortic diastolic murmur in left } \\
\text { ventricle. No systolic pressure } \\
\text { gradient across valve. Moder- } \\
\text { ate (grade } 2 / 4 \text { ) valve calcifica- } \\
\text { tion. Angiogram: Severe }\end{array}$ & $\begin{array}{l}\text { Clinically: moderate incompe- } \\
\text { tence (grade 2). Right atrium } \\
\text { moderately enlarged (grade } \\
2 / 4 \text { ). Right atrial mean pressure } \\
5 \mathrm{~mm} . \mathrm{Hg}\end{array}$ & $\begin{array}{l}\text { R.V.P. } 46 / 5 \text {. } \\
\text { Normal resistance }\end{array}$ & $\begin{array}{l}\text { Asymptomatic. Work- } \\
\text { ing full time } 2 \text { years } \\
\text { and } 2 \text { months' post- } \\
\text { operatively. C.T.R. } \\
\text { reduced from } 75 \text { to } \\
64 \%\end{array}$ \\
\hline 3 & $\mathbf{F}$ & 56 & $\begin{array}{l}\text { Grade } 2 b \\
\text { dyspnoea. } \\
\text { C.C.F. }\end{array}$ & $\begin{array}{l}\text { Clinically: mixed stenosis } \\
\text { and incompetence. } \\
\text { Angiogram: grade } 2 \\
\text { incompetence and grade } \\
2 \text { left atrial enlargement }\end{array}$ & $\begin{array}{l}\text { Clinically: mild incompetence. } \\
\text { Catheter: passed across valve } \\
\text { on a loop and therefore no } \\
\text { stenosis. No pressure gradient } \\
\text { across valve. L.V.E.D.P. } \\
4 \mathrm{~mm} \text {.Hg. Left ventricular } \\
\text { cavity grade } 2 \text { enlargement. } \\
\text { Surgery: moderate incom- } \\
\text { petence }\end{array}$ & $\begin{array}{l}\text { Clinically: tricuspid incompe- } \\
\text { tence gross (grade 4) on admis- } \\
\text { sion, moderate (grade 2) after } \\
\text { intensive therapy. Catheter: } \\
\text { loud pansystolic murmur in } \\
\text { right atrium on intracardiac } \\
\text { phonocardiography. } 5 \text { mm.Hg } \\
\text { pressure gradient across tricus- } \\
\text { pid valve in diastole. R.A.P. }\end{array}$ & $\begin{array}{l}\text { P.A.P. mean } \\
24 \mathrm{~mm} \text {. Hg. } \\
\text { Normal resistance }\end{array}$ & $\begin{array}{l}\text { Two years postopera- } \\
\text { tively condition } \\
\text { improved, but dys- } \\
\text { pnoeic still grade 2b. } \\
\text { C.T.R. reduced } \\
\text { from } 75 \text { to } 68 \%\end{array}$ \\
\hline 4 & F & 22 & $\begin{array}{l}\text { Grade } 3 \\
\text { dispnoea. } \\
\text { C.C.F. }\end{array}$ & $\begin{array}{l}\text { Clinically: grade } 3 \text { incom- } \\
\text { petence. Catheter: } \\
\text { P.A.W. 20. Angiogram: } \\
\text { grade } 3 \text { incompetence }\end{array}$ & $\begin{array}{l}\text { Clinically: mixed stenosis and } \\
\text { incompetence grade } 2 \text {. Cathe- } \\
\text { ter: } 50 \text { mm.Hg gradient across } \\
\text { valve. Angiogram: grade } 2\end{array}$ & $\begin{array}{l}\text { No clinical evidence of disease } \\
\text { after treatment but R.A. was } \\
\text { grade } 2 \text { enlarged. Catheter: } \\
\text { R.A.P. 10/6 }\end{array}$ & $\begin{array}{l}\text { P.A.P. 50/20. Mean } \\
\text { 30. L.A.P. mean } \\
20 \text {. Normal } \\
\text { resistance }\end{array}$ & $\begin{array}{l}\text { Lost to detailed } \\
\text { follow-up in Africa }\end{array}$ \\
\hline 5 & $\mathbf{F}$ & 37 & $\begin{array}{l}\text { Grade } 3 \\
\text { dyspnoea. } \\
\text { Angina. } \\
\text { C.C.F. }\end{array}$ & $\begin{array}{l}\text { Clinically: grade } 3 \text { incom- } \\
\text { petence. Catheter: con- } \\
\text { firmed this. } \quad \text { L.A.P. } \\
40 / 12\end{array}$ & $\begin{array}{l}\text { Incompetence } \\
\text { Clinically: grade } 3 \text { stenosis and } \\
\text { grade } 3 \text { incompetence. Cathe- } \\
\text { ter: left ventricle not entered. } \\
\text { Grade } 2 \text { incompetence on }\end{array}$ & $\begin{array}{l}\text { Clinically: grade } 2 \text { incompetence. } \\
\text { No clinical evidence of stenosis. } \\
\text { Catheter: Systolic murmur in } \\
\text { R.V. }\end{array}$ & $\begin{array}{l}\text { R.V.P. } 40 / 4 . \\
\text { Normal } \\
\text { resistance }\end{array}$ & $\begin{array}{l}\text { Much improved, but } \\
\text { died of massive } \\
\text { cerebral infarction } \\
4 \frac{1}{2} \text { months later }\end{array}$ \\
\hline 6 & $\mathbf{F}$ & 38 & $\begin{array}{l}\text { Grade } 3 \\
\text { dyspnoea. } \\
\text { Ascites. } \\
\text { C.C.F. }\end{array}$ & $\begin{array}{l}\text { Clinically: grade } 2 \text { steno- } \\
\text { sis and grade } 2 \text { incom- } \\
\text { petence. Angiogram: } \\
\text { grade } 2 \text { incompetence }\end{array}$ & $\begin{array}{l}\text { Clinically: no stenosis, grade } 1 \\
\text { incompetence. Catheter: no } \\
\text { gradient across valve. Grade } 2 \\
\text { incompetence diagnosed on }\end{array}$ & $\begin{array}{l}\text { Clinically: grade } 3 \text { incompetence. } \\
\text { Catheter: } 22 \mathrm{~mm} . \mathrm{Hg} \text {. C.V. } \\
\text { wave }\end{array}$ & $\begin{array}{l}\text { R.V.P. } 40 / 8 \text {. } \\
\text { Normal } \\
\text { resistance }\end{array}$ & $\begin{array}{l}\text { Died on 5th post- } \\
\text { operative day of low } \\
\text { cardiac output }\end{array}$ \\
\hline 7 & $\mathbf{F}$ & 48 & $\begin{array}{l}\text { Grade } 3 \\
\text { dyspnoea. } \\
\text { Angina. } \\
\text { C.C.F. }\end{array}$ & $\begin{array}{l}\text { Clinically: stenosed valve } \\
\text { with incompetence pre- } \\
\text { vious valvotomy). Cath- } \\
\text { eter: L.A.P. mean of } \\
10 \mathrm{~mm} . \mathrm{Hg} \text { wave in } \\
\text { L.A. of } 19 \mathrm{~mm} . \mathrm{Hg}\end{array}$ & $\begin{array}{l}\text { Clinically: grade } 2 \text { stenosis and } \\
\text { grade } 2 \text { incompetence. B.P. } \\
110 / 60 . \text { Catheter: } 3 \mathrm{~mm} \text {.Hg } \\
\text { gradient across valve. Angio- } \\
\text { gram: grade } 2 \text { incompetence }\end{array}$ & $\begin{array}{l}\text { No clinical evidence of disease } \\
\text { after treatment. Catheter: } \\
3 \mathrm{~mm} \text {.Hg diastolic gradient } \\
\text { across valve. No murmur in } \\
\text { R.A. }\end{array}$ & $\begin{array}{l}\text { R.V.P. } 40 / 0 . \\
\text { Normal } \\
\text { resistance }\end{array}$ & $\begin{array}{l}\text { Working full time } 15 \\
\text { months'postopera- } \\
\text { tively. Now in sinus } \\
\text { rhythm. Dyspnoea } \\
\text { grade i. C.T.R. } \\
\text { reduced from } 59 \text { to }\end{array}$ \\
\hline 8 & $\mathbf{F}$ & 52 & $\begin{array}{l}\text { Grade } 2 b \\
\text { dyspnoea. } \\
\text { Angina. } \\
\text { C.C.F. } \\
\text { Orthopnoea }\end{array}$ & $\begin{array}{l}\text { Clinically: grade } 3 \text { incom- } \\
\text { petence. Angiogram: } \\
\text { grade } 2 \text { incompetence }\end{array}$ & $\begin{array}{l}\text { Clinically: grade } 3 \text { incompetence, } \\
\text { with some stenosis. B.P. } \\
120 / 50 . \text { Angiogram: grade } 3 \\
\text { incompetence }\end{array}$ & $\begin{array}{l}\text { Clinically: grade } 2 \text { incompetence. } \\
\text { Catheter: diastolic gradient } \\
\text { across valve. No systolic } \\
\text { murmur in R.A. Diastolic }\end{array}$ & $\begin{array}{l}\text { P.A.P. } 55 / 18 \text {, mean } \\
35 . \text { Grade } 1-2 \\
\text { increase in } \\
\text { resistance }\end{array}$ & $\begin{array}{l}\text { Died on 17th post- } \\
\text { operative day }\end{array}$ \\
\hline 9 & $\mathrm{~F}$ & 43 & $\begin{array}{c}\text { Grade } 4 \\
\text { dyspnoea. } \\
\text { C.C.F. }\end{array}$ & $\begin{array}{l}\text { Clinically: grade } 3 \text { incom- } \\
\text { petence and grade } 2 \\
\text { stenosis. Catheter: V } \\
\text { wave in L.A. of } 28 \mathrm{~mm} \text {. } \\
\text { Hg. Mean L.A.P. = } \\
\mathbf{2 4} \mathrm{mm} . \mathrm{Hg}\end{array}$ & $\begin{array}{l}\text { Clinically: grade } 2 \text { stenosis and } \\
\text { grade } 2 \text { incompetence. Cathe- } \\
\text { ter: } 50 \mathrm{~mm} \text {. Hg gradient across } \\
\text { valve. Angiogram: grade } 2 \\
\text { incompetence }\end{array}$ & $\begin{array}{l}\text { Clinically: grade } 3 \text { incompetence. } \\
\text { R.A. grade } 3 \text { enlarged on radio- } \\
\text { graph. Catheter: Mean dias- } \\
\text { tolic gradient of } 5 \mathrm{~mm} \text {. Hg } \\
\text { across valve }\end{array}$ & $\begin{array}{l}\text { P.A.P. } 34 / 5 . \\
\text { Normal } \\
\text { resistance }\end{array}$ & $\begin{array}{l}\text { Working full-time } 8 \\
\text { months' postopera- } \\
\text { tively. J.V.P. } 3 \mathrm{~cm} \text {. } \\
\text { increased. C.T.R. } \\
\text { reduced from } 58 \text { to } \\
55 \%\end{array}$ \\
\hline
\end{tabular}

Dyspnoea is graded 1, 2a, 2b, 3, 4, according to the criteria of the late Paul Wood. All other gradings, 1, 2, 3, 4, meaning slight, moderate, severe, and gross. C.C.F. $=$ Congestive cardiac failure. C.T.R. $=$ Cardiothoracic ratio. J.V.P. = Jugular venous pressure. R.A.P. $=$ Right atrial pressure. R.A. = Right atrium. L.A.P. =
Left atrial pressure. L.A. $=$ Left atrium. Left atrial pressure. L.A. = Left atrium. P.A.P. = Pulmonary artery pressure. P.A. = Pulmonary

All pressures measured from the sternal angle. All patients except Cases 4 and 5 were catheterized without sedation.

this regimen in four. An inspiratory tricuspid pansystolic murmur was still audible in two of these, as it was in all five with raised venous pressure. None had any dependent oedema at the time of surgery. When the patient had been brought to his optimal condition estimation of valve incompetence clinically, at cardiac catheterization, and at surgery correlated fairly accurately. The haemodynamic characteristics of the individual valves are outlined in the Table.

The mitral valve was the primarily affected valve in every case, owing to severe regurgitation in six patients and moderately severe stenosis with regurgitation in three (see Table). The aortic valve was severely incompetent in three patients and moderately severely incompetent in six. There was a moderate degree of stenosis also in five. All patients had some tricuspid incompetence when ambulant on full medical treatment. At St. Thomas's Hospital the tricuspid valve has been replaced only if there has been organic valve disease with thickening and fibrosis of the cusps. Tricuspid stenosis was slight $(2.5$ to $3 \mathrm{~cm}$. orifice) in four patients and moderate $(2 \mathrm{~cm}$. orifice) in one. Two had an end-diastolic gradient across the valve at the time of cardiac catheterization. Tricuspid incompetence was found by palpation to be pronounced at the time of surgery in seven patients and moderate in two.

\section{Assessment of Complicating Factors}

Three factors that affect the immediate operative mortality and morbidity of valve replacement are the pulmonary vascular resistance, the state of the myocardium, and whether the patient has had a previous mitral valvotomy. All the patients in this series had a normal pulmonary vascular resistance.

The state of the myocardium cannot yet be accurately assessed in the presence of multiple valve disease. If the myocardium is in poor shape and cardiac output is low the patient may be wasted. The two patients who died in our series showed appreciable wasting of skeletal muscles and subcutaneous tissues, and both died as a result of low cardiac output in the postoperative period. A previous mitral valvotomy increases the hazards of multiple valve replacement because the process of freeing adhesions in the pericardium tends to embarrass cardiac function before cardiopulmonary bypass can be begun, and because bleeding from the divided adhesions is more difficult to control after the necessarily long periods of bypass. Two of the three who had had previous mitral valve surgery had to be returned to the theatre for haemostasis on the night of the operation.

\section{Preoperative Preparation}

Patients who had had to be discharged after cardiac catheterization were admitted to hospital for two weeks before operation for bed rest and treatment of heart failure until the jugular venous pressure and body weight were again reduced to a minimum. Potassium supplements were continued, but digoxin and diuretics were stopped three to five days before operation, and the cardiac status was maintained by strict bed rest alone. Fluid retention could be appreciable at this time- 
the largest gain was $5 \mathrm{~kg}$.- - but was felt to be less important than the risks of overdigitalization and further potassium depletion. As a result of this policy patients passed large quantities of urine when an adequate circulation was provided by cardiopulmonary bypass. The patient who had gained $5 \mathrm{~kg}$. passed 4 litres $(4 \cdot 2 \mathrm{~kg}$.) at this time.

\section{Operative Technique}

The operative technique was essentially that developed by Starr with minor variations.

Anaesthesia.-This was induced with nitrous oxide and oxygen. Thiopentone was not used as it had been found to cause considerable hypotension, which sometimes necessitated emergency institution of bypass in patients with such mechanically damaged hearts.

Incisions. - A median sternotomy was used in each case. Separate incisions were made in each atrium, the left atrial incision being carried behind the heart to allow the right heart to be retracted to the left and to expose the mitral valve, which was pulled further into view by stay sutures.

Pump Oxygenator.-A pump oxygenator suitable for triple valve replacement should be able to oxygenate blood fully without significant haemolysis for up to five hours. The OsbornBramson-Gerbode large disc oxygenator satisfies these requirements and was used for all operations. Bypass lasted between three and a half and four and three-quarter hours in this series, and at no time did the arterial oxygen tension fall below 100 $\mathrm{mm}$. Hg. The postperfusion plasma haemoglobin was on average 95 (45 to 175$) \mathrm{mg} . / 100 \mathrm{ml}$.

\section{Myocardial Preservation}

The myocardium was preserved by intermittent cold perfusion of both coronary arteries. At intervals of 15 minutes the coronary arteries were perfused for three minutes. Blood at $8^{\circ} \mathrm{C}$. was pumped through hand-held catheters from separate calibrated coronary pumps, each with its own line pressure gauge. A thermistor probe inserted in the interventricular septum allowed the adequacy of myocardial cooling to be checked. The remainder of the patient was perfused at a temperature of $30^{\circ} \mathrm{C}$.

The aorta was occluded for between two hours and two hours forty minutes while the mitral and then the aortic valves were replaced. Adequacy of myocardial preservation was confirmed by there being no difficulty in restarting the heart or discontinuing the bypass in any patient.

\section{Individual Valve Replacement}

The mitral and aortic valves were replaced with the aorta occluded. The aorta was then closed and the aortic clamp removed, so that the coronary arteries were perfused with blood at $30^{\circ} \mathrm{C}$. in the aorta. The tricuspid valve was then replaced. Two further short periods of occlusion were required while stitches were inserted and the valve was tied down over the area of the bundle of His.

The size of each prosthesis was chosen to fit the appropriate ventricle or aorta rather than the valve ring. This has been shown to be critical for the proper functioning of Starr valves, as many of the complications associated with ball valves are due to too large a prosthesis having been chosen. Four mitral and five tricuspid prostheses were small $(2 \mathrm{M})$, as were six aortic prostheses ( 7 and $8 \mathrm{~A})$. The small size of the aorta is a particular feature of multiple valve disease, presumably owing to the previous low cardiac output.

Vertical mattress sutures of fatigue-resistant Teflon-coated Dacron (Tevdek) were used to secure the maximum depth of valve ring in contact with the sewing-cuff of the prosthesis. This technique was time-consuming and required more sutures (26 to 35 ) for each valve than the more commonly employed horizontal mattress or double-throw sutures, but time was thought to be less important than precision. Accuracy was further enhanced by the intermittent cold coronary perfusion, because stitches could be inserted in a still and totally relaxed heart and tied down without risk of their cutting out. The value of the precision obtainable in this way was shown by the fact that no valve in the entire series has been shown to leak, though one patient has a murmur that could be attributed to mitral incompetence, but she declines further investigation.

After closure of the atria the heart was restarted with internal or, in reoperation cases, external D.C. fibrillation. Pacemaker wires were inserted in the right ventricle, and atrial pressure lines were placed in the left atrium and in the inferior vena cava.

\section{Postoperative Management}

Organic triple valve disease implies severe rheumatic heart disease and myocardial damage, but a notable feature of triple valve replacement in our hands is that there have been fewer postoperative problems than after double valve replacement. Positive-pressure ventilation was routinely continued until the circulatory state was satisfactory. An elective tracheostomy was performed at the time of surgery in the first patient in the series, but subsequently only plastic endotracheal tubes were used, positive-pressure ventilation being continued for 3 to 10 days, with an average of six days. Sedation was relatively heavy while the orotracheal tube was in place, Omnopon in dosages of 10 to $20 \mathrm{mg}$. being alternated with phenoperidine $2 \mathrm{mg}$. every two to four hours.

Blood was transfused to maintain the higher of the two atrial pressures at as low a level as would achieve an adequate cardiac output. The left atrial pressure was usually 5 to 10 $\mathrm{mm} . \mathrm{Hg}$, measured from the sternal angle. Plasma was used instead of blood if the packed cell volume rose above $45 \%$. The cardiac output and tissue perfusion were assumed to be adequate if urine output exceeded $30 \mathrm{ml}$./hour, there was no metabolic acidosis, the $\mathrm{PaO}_{2}$ on $40 \%$ oxygen was above 100 $\mathrm{mm}$. $\mathrm{Hg}$, and the warmth and venous tone of the feet were normal.

All patients except the first received continuous intravenous isoprenaline until the circulatory state was felt to be stable. Digoxin was given hesitantly early in the series but with increasing confidence later, when it was appreciated that any bradycardia could be corrected by the pacemaker wires inserted at operation and the heart rate kept between 90 and 100 /minute with demand pacing. A low cardiac output not responding to isoprenaline, digoxin, and pacemaking was treated in three patients with glucose, insulin, and potassium (50 units insulin, $50 \%$ glucose, and $50 \mathrm{mEq}$ potassium) by intravenous infusion.

Arrhythmias were controlled with lignocaine (1-2 mg./min.) and potassium, the dosage of the latter being related to its concentration in the serum and urine. Pacemaking with the ventricular wires was often necessary for temporary episodes of atrioventricular dissociation developing in the postoperative period. Such dissociation was presumably due to the rigid tricuspid prosthesis, as it has rarely occurred after aortic and mitral valve replacement. The longest period of dissociation was three days. Ventricular arrhythmias unresponsive to potassium, lignocaine, and pacemakers were treated with $50 \%$ glucose, insulin, and potassium.

Infection with Staphylococcus albus or aureus used to be a common complication of prosthetic valve replacement until the introduction of intensive prophylactic antibiotic regimens. Ampicillin $(0.5$ g.) and methicillin ( $1 \mathrm{~g}$.) daily were given for three weeks to all patients in this series, and no patient developed endocarditis or wound infection. 


\section{Results}

The results of triple valve replacement were assessed by mortality, morbidity, and postoperative improvement in symptoms.

Operative Mortality.-Two patients died during their hospital admission, an operative mortality of $22 \%$. Both were cachectic before operation with very low cardiac outputs, and in retrospect they did not have the myocardial reserve to tolerate the extensive procedure. They were in fact described by the cardiological department as patients with "three incompetent valves and no heart in between." One died of a persistent low cardiac output on the fifth postoperative day, and the second died of hepatorenal failure on the 17th postoperative day, though her cardiac output appeared to have returned to an adequate level by that time.

Late Mortality.-There was one late death four months after operation, from cerebral embolism. The left atrial wall was covered with clot in spite of adequate control of anticoagulant therapy. The Starr valves were free of thrombus.

Morbidity.-The surviving patients had relatively smooth postoperative courses if one considers their preoperative condition and the extensive procedure. Two of the three patients who had had previous mitral valvotomies had to be returned to the operating-theatre for haemostasis. Another patient had an extensive haematoma in the leg after an intramuscular injection and one developed hepatic and renal emboli, from which she recovered completely. Five had early benign and transient jaundice, and one died with hepatorenal failure.

Functional Results.-All the surviving patients are symptomatically improved. At follow-up five months to two years after operation three of them were working full time. One was lost to detailed follow-up in Africa. Two were living as housewives, one of these being still limited in activity. All required digoxin and two required diuretics also. The hearts of all but one patient have diminished in size radiologically, the mean reduction in cardiothoracic ratio being from 66 to $60 \%$ (see Table). One patient has had no reduction in heart size, but her heart was the smallest of the series (Special Plate, Figs. 2 and 3).

Two have persistently raised jugular venous pressures. One patient was thought to have tricuspid incompetence after a systolic murmur had been shown by intracardiac phonocardiography in the right atrium, but on re-exploration 11 months after the initial operation this murmur was found to be either the aortic Starr valve ejection murmur transmitted to the right atrium or a degree of incompetence around the medial edge of the mitral valve. The tricuspid valve prosthesis was completely competent. This syndrome of a raised jugular venous pressure in the presence of a fully competent tricuspid valve has been described by Starr (1968) and attributed to poor right ventricular function.

\section{Discussion}

Triple valve replacement is necessarily a relatively rare operation, as many patients with such severely damaged valves will have died before the operation became available. Starr reports 33 patients who have had triple Starr valve replacements (Bigelow et al., 1968). A recent report from the Mayo Clinic quotes 25 triple valve replacements out of a total of 1,355 valve replacements (Duvoisin et al., 1968). Most published series report only small numbers of cases.

Before recommending triple valve replacement the low but definite incidence of complications associated with Starr ball valves needs to be borne in mind. Infection of a Starr ball valve prosthesis used to be relatively common but now can be largely prevented by prophylactic antibiotics and removal of teeth (Amoury et al., 1966; Windsor et al., 1968). Leaks around the valve seating, haemolysis, and irritation of the ventricular septum occur but can be kept to a minimum by precise suture techniques with fatigue-resistant sutures and accurate sizing and positioning of the valve (Herr et al., 1965 ; Roberts and Morrow, 1966). So-called ball variance may occur in about $10 \%$ of aortic Starr valve replacements due to hardening, deformation, and cracking of the older Silastic (siliconized rubber) ball (Starr et al., 1968). Thrombosis occurs on the cloth/steel interface of mitral ball valves and used to cause embolism in some $20 \%$ of patients, though the incidence is less if the patient is in sinus rhythm and effectively anticoagulated (Akbarian et al., 1968). These last two complications have been reduced by the introduction of the new steel ball and totally cloth-covered Starr prosthesis (Bigelow et al., 1968). At the present time, even if the operative mortality were negligible, we believe that a patient with a prognosis of four years or more without surgery should not be offered valve replacement, and we do not therefore recommend triple valve replacement unless the patient is handicapped.

Replacement of a significantly incompetent aortic valve at the time of mitral valve replacement has become accepted as necessary for a smooth postoperative course and ultimately satisfactory effort tolerance (Starr et al., 1964 ; Bigelow et al., 1968). The area of discussion in surgery of multiple valve disease has now become the diagnosis and management of tricuspid incompetence.

\section{Assessment of Incompetence}

Surgical assessment of tricuspid incompetence has been necessary in addition to clinical and catheter studies because of the difficulty of diagnosing tricuspid incompetence before operation. Starr states that tricuspid incompetence severe enough to demand replacement was missed clinically and at cardiac catheterization in as many as $12 \%$ of his patients (Bigelow et al., 1968). The relative value of each of these methods in estimation of incompetence in triple valve disease is debated because incompetence of individual tricuspid valves varies so much, depending on the cardiac condition at the time of the individual test. At the clinical examination a false estimate of the degree of tricuspid incompetence can be made if the cardiac output is low or fluid retention is pronounced. At cardiac catheterization incompetence may be overestimated and stenosis underestimated if sedation, anaesthesia, or ectopic beats have lowered the cardiac output. Critical stenosis-that is, stenosis severe enough to produce an end-diastolic gradient-of the tricuspid valve has not been as well studied as it has in mitral stenosis, but a pressure gradient across the tricuspid valve at cardiac catheterization does not seem to appear unless the valve is narrowed to almost $3 \mathrm{~cm}$. in diameter, a situation that does in fact correlate with the experience of mitral stenosis.

At the time of surgery stenosis can be accurately measured, but the assessment of incompetence is unreliable in a patient whose cardiac output has deteriorated after anaesthesia and manipulation of the heart, and the degree of tricuspid incompetence is also affected by the right atrial pressure at the time of palpation of the valve.

The management of tricuspid incompetence also varies in different centres. Some believe that tricuspid incompetence is relatively unimportant except in the immediate postoperative period. Others believe that important tricuspid incompetence discovered at the time of surgery never resolves, and restricts the ultimate success of the operation (Bigelow et al., 1968). Our policy has been to replace an incompetent tricuspid valve only if it is organically diseased with fibrosis of the cusps. This policy is dictated by the difficulty of suturing a prosthetic valve into normal flimsy tricuspid valve tissue, because stitches have to be placed in the valve leaflet itself over the area of the bundle of His in order to avoid complete heart block, and are then likely to tear out. 


\section{Technique}

The operative technique used for triple valve replacement varies widely, but an oxygenator that will oxygenate well and without excessive trauma to the blood after five hours of perfusion is necessary for consistent success. A patient with heavily calcified valves who has had a previous valvotomy causing a densely adherent pericardium requires a considerable period of cardiopulmonary bypass because of the difficulties of mobilizing the heart, obtaining an adequate view of the valves, and placing stitches accurately into poor tissue. The Osborn-BramsonGerbode oygenator used in this series oxygenated blood fully for up to four and three-quarter hours with little trauma to the blood.

Precision in the placement of sutures and tying down the valve can be helped by the method of myocardial preservation chosen. The still, cold relaxed heart produced by intermittent cold coronary perfusion in this series was ideal for careful suture technique. The size of the prosthetic valves that need to be used in multiple valve replacement tends to be smaller than in single valve disease (Bigelow et al., 1968). This was true also of this series, where most of the valves used were of the smallest sizes.

\section{Postoperative Management}

Postoperative management of multiple valve replacement at St. Thomas's Hospital has differed little from that of most cardiac surgical units but has emphasized prolonged positivepressure ventilation with oral endotracheal tubes, the importance of knowing the filling pressures of both ventricles in the first few days, the maintenance of venous filling pressures as low as practicable rather than as high as possible, and the use of isoprenaline and implanted pacemaker wires.

Pulmonary function and ventilation/perfusion imbalance has been shown to deteriorate for two to three days after cardiopulmonary bypass and then improve (Fordham and Resnekov, 1967). During this period only minimal sedation can be given because of the risk of retention of secretions and subsequent atelectasis. Positive-pressure ventilation by an orotracheal tube was used in this series and allowed full inflation of the lungs, regular clearing of bronchial secretions, and adequate sedation to be given (Clement and Hubsch, 1968). The $\mathrm{PaO}_{2}$ did not fall below $100 \mathrm{~mm}$. $\mathrm{Hg}$ in the first two to three days, though it consistently fell up to that time before improving. It was noticeable that arrhythmias were more common immediately after positive-pressure ventilation had been discontinued. There were no complications attributable to the length of time the orotracheal tube has been left in place.

A policy frequently recommended in postoperative cardiac management is maintenance of a high mean right atrial pressure (12 to $25 \mathrm{~mm}$. $\mathrm{Hg}$ ), though the literature on this subject is bedevilled by the fact that the reference point for postoperative venous pressure measurements is often omitted. This policy is based on the thesis that both atrial pressures tend to be similar and that the left ventricular function curve is fairly steep, so that raising its filling pressure will improve its stroke volume. The left atrial filling pressure was, however, found to bear little relation to that on the right after triple valve replacement, and a difference of 10 to $15 \mathrm{~mm}$. $\mathrm{Hg}$ between them was frequently observed.

The left ventricular function curves of most patients with multiple valve disease are also almost flat and raising the filling pressure produces little improvement in stroke volume (Bradley, 1969). Our policy has therefore been to keep such patients at as low a filling pressure as will maintain an adequate cardiac output or, if still inadequate, at as good a cardiac output as can be obtained.

The relatively low fixed stroke volume of these patients will allow an adequate cardiac output only if the heart rate can be maintained at a satisfactory level. After surgery isoprenaline was used by continuous intravenous infusion in all patients to maintain a heart rate about $90 /$ minute. Isoprenaline also improved the myocardial contractility and stroke volume (Bradley, 1969). Digoxin and calcium were given for the same purpose; digoxin, however, tends to produce a bradycardia which may outweigh its effect in improving the stroke volume. Pacemaker wires were therefore inserted in the right ventricular wall at the time of surgery in all patients in this series, and were used to maintain the pulse rate about $90 /$ minute at all times when isoprenaline was ineffective for this purpose. Complete heart block developed temporarily and required pacing after return to the intensive care unit in three patients, owing presumably to the rigid tricuspid prosthesis, because this complication has not been seen after aortic and mitral valve replacement alone.

\section{Results}

The results in terms of mortality and morbidity in this series were acceptable in view of the preoperative condition of the patients. Starr reported a $12 \%$ operative and $12 \%$ late mortality, and the Mayo Clinic reported a $28 \%$ operative and $29 \%$ late mortality (Bigelow et al., 1968 ; Duvoisin et al., 1968). The operation mortality in the present series was $22 \%$ and late mortality $9 \%$.

The most frequent postoperative complication was jaundice, of which three types may be recognized after open heart surgi:-: The benign form is characterized by early appearance of jaundice, little evidence of hepatic damage, and resolution without permanent ill effects. The malignant form develops later and progresses relentlessly to death from hepatic failure, often with renal failure also. The third type is homologous serum jaundice, which appears months later. In $53 \%$ of Starr's series of triple valve replacements the patient became jaundiced. No patient in the present series developed homologous serum jaundice, but five of the nine suffered from early benign jaundice, and one died of hepatorenal failure.

Follow-up after triple valve replacement has necessarily been relatively short. Of the Mayo Clinic series $42 \%$ of patients were still alive after two and a half years, the major cause of death after leaving hospital being thromboembolism, though the series involved many of the earliest types of prosthesis (Duvoisin et al., 1968). Starr, however, found the incidence of thromboembolism to be no greater after multiple than after mitral valve replacement alone, and that it had been greatly reduced after the introduction of the newer prostheses (Bigelow et al., 1968). The one late death in the St. Thomas's series was due to thromboembolism originating from the atrial wall and not the prosthetic valves.

The character of life after triple valve replacement must be improved if its value is to be established. In Starr's series a profound fall was usually observed in left atrial pressures, in spite of the frequent use of small-size mitral prostheses (Bigelow et al., 1968). The left atrial end-diastolic pressures were usually normal at rest, and a satisfa?tory exercise response was obtained in all but one. This is reflected in the fact that two-thirds of his patients were well after surgery. Most of the remainder were greatly improved but had some effort intolerance and required salt restriction. Three patients did not, however, have a good haemodynamic result. One had leaks around the prosthetic valves, but improved after repair at reoperation. One subsequently died of coronary artery disease, and the third had persistent cardiomegaly with suspected myocardial fibrosis.

In the St. Thomas's series all but one patient followed up had little effort intolerance and were at full-time work. The one exception was still limited in the amount of activity possible but had improved. All patients but the one with the smallest heart have shown a reduction in heart size. 
Our grateful thanks are due to Professor Timothy Counihan and Drs. Raymond Daley, John Horman, Arthur Hollman, Evan Jones, and Desmond Julian, whose patients these were, for permission to publish these data.

\section{REFERENCES}

Akbarian, M., Austen, W. G., Yurchak, P. M., and Scannell, J. G. (1968). Circulation, 37, 826

Amoury, R. A., Bowman, F. O., and Malm, J. R. (1966). Fournal of Thoracic and Cardiovascular Surgery, 51, 36.

Bigelow, J. C., Herr, R. H., Wood, J. A., and Starr, A. (1968). Circula38, 656

Bradley, R. (1969). Unpublished data.

Clement, A. J., and Hubsch, S. K. (1968). Physiotherapy (London), 54, 355.

Cooley, D. A., Bloodwell, R. D., and Hallman, G. L. (1968). Fournal of Cardiovascular Surgery, 9, 403.
Duvoisin, G. E., Wallace, R. B., Ellis, F. H., Anderson, M. W., and McGoon, D. C. (1968). Circulation, Suppl. No. 2, p. 75.

Fordham, R. M. M., and Resnekov, L. (1967). Cardiovascular Research, 1, 159 .

Herr, R., Starr, A., McCord, C. W., and Wood, J. A. (1965). Annals of Thoracic Surgery, 1, 403.

Roberts, W. C., and Morrow, A. G. (1966). American fournal of Cardiology, 18, 497.

Starr, A. (1968). Multiple valve replacement. Delivered at European Society of Cardiovascular Surgeons, London.

Starr, A., Edwards, M. L., McCord, C. W., Wood, J., Herr, R., and Griswold, H. E. (1963). Multiple valve replacement. Issued by Griswold, H. E. (1963). Multiple valve replacement. Issued

Department of Surgery, University of Oregon Medical School. ball variance following aortic replacement. Edwards Laboratories Distribution

Starr, A., McCord, C. W., Wood, J., Herr, R., and Edwards, M. L. (1964). Annals of Surgery, 160, 596.

Windsor, H. M., Fagan, P., and Shanahan, M. X. (1968). Thorax, 23, 11.

\title{
Diabetes and Oesophageal Dysfunction
}

\author{
W. SILBER,* M.B., CH.B., F.R.C.S.ED.
}

British Medical fournal, 1969, 3, 688-690

\begin{abstract}
Cummary : Cineradiographic and manometric studies of oesophageal function were carried out in four different groups of patients (those suspected of having oesophageal disease, with and without symptoms ; and in two groups of diabetes, with and without diabetic neuropathy). All groups were found to have abnormal oesophageal function, and this was not commoner in those with diabetic neuropathy.
\end{abstract}

\section{Introduction}

Neurological complications of long-standing diabetes are well known. The effects on the gastrointestinal tract have also been well documented, but not those on the oesophagus. Oesophageal dysfunction in diabetic neuropathy has been specifically investigated clinically and cineradiographically (Mandelstam and Leiber, 1967). Subsequently it has been suggested that further information might be gained by the use of intraluminal manometry (British Medical fournal, 1967). It was for these reasons that the present study was undertaken.

\section{Methods and Results}

Routine cineradiographic and manometric studies of the oesophagus were performed during the past year on all patients in this series. The patients, who ranged in age from 30 to 75

\begin{tabular}{|c|c|c|c|c|}
\hline Group & $\begin{array}{c}\text { No. } \\
\text { of } \\
\text { Cases }\end{array}$ & $\begin{array}{c}\text { No. with } \\
\text { Oesophageal } \\
\text { Symptoms }\end{array}$ & $\begin{array}{l}\text { No. with } \\
\text { Abnormal } \\
\text { Cineradio- } \\
\text { graphic } \\
\text { Changes }\end{array}$ & $\begin{array}{l}\text { No. with } \\
\text { Abnormal } \\
\text { Manometric } \\
\text { Findings }\end{array}$ \\
\hline $\begin{array}{l}\text { 1. Non-diabetic and asympto- } \\
\text { matic . . . . . } \\
\text { 2. Non-diabetic and symptomatic } \\
\text { 3. Diabetic unassociated with }\end{array}$ & $\begin{array}{l}20 \\
20\end{array}$ & $\stackrel{0}{20}(100 \%)$ & $\begin{array}{r}4(20 \%) \\
14(70 \%)\end{array}$ & $\begin{array}{r}9(45 \%) \\
14(70 \%)\end{array}$ \\
\hline $\begin{array}{ll}\text { neuropathy } & \cdots \\
\text { 4. Diabetic with neuropathy } & \cdots\end{array}$ & $\begin{array}{l}20 \\
20\end{array}$ & $\begin{array}{l}8(40 \%) \\
8(40 \%)\end{array}$ & $\begin{array}{l}5(25 \%) \\
11(55 \%)\end{array}$ & $\begin{array}{l}12(60 \%) \\
12(60 \%)\end{array}$ \\
\hline
\end{tabular}

* Senior Surgeon, Groote Schuur Hospital, Observatory, Cape Town ; Senior Lecturer, Department of Surgery, University of Cape Town, South Africa.

Reprints from: Oesophageal Clinic, Department of Surgery, Groote Schuur Hospital, Observatory, Cape Town, South Africa. (mean 38) years, were subdivided into four groups (see Table), each group consisting of 20 cases matched in age and sex. The manometric studies were carried out by means of three waterfilled Portex tubes with lateral openings attached to external transducers and a Beckman Dynograph pressure-recording machine.
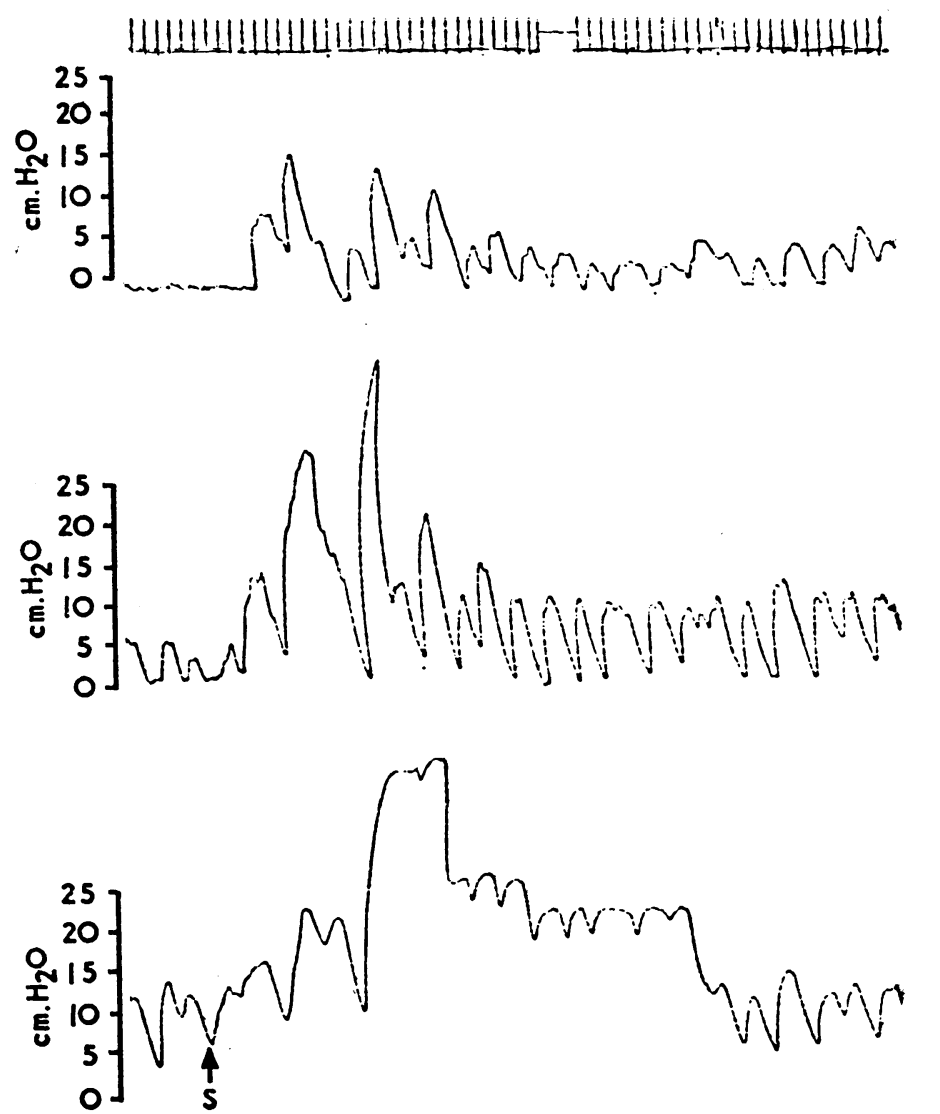

Fig. :-Incoordizated peristalsis. $S=$ Swallow. 
M. V. BRAIMBRIDGE $E T A L$ : TRIPLE STARR VALVE REPLACEMENT

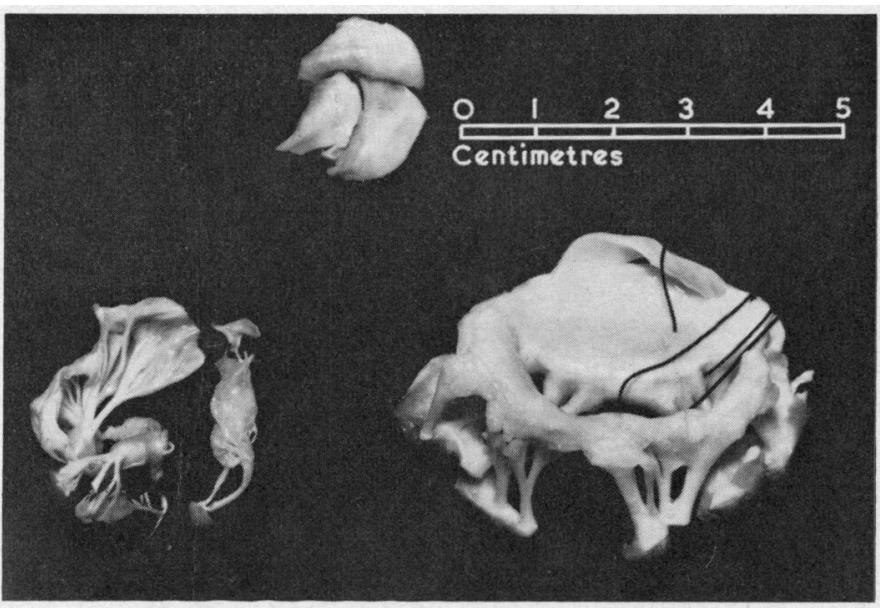

Fig. 1

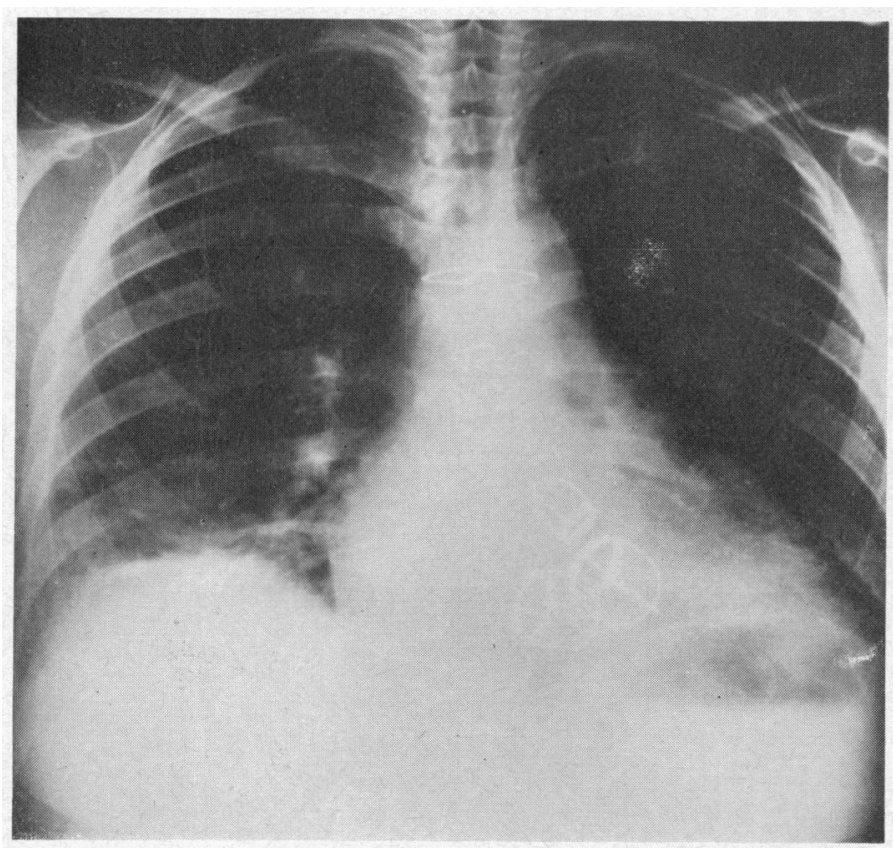

FIG. 2

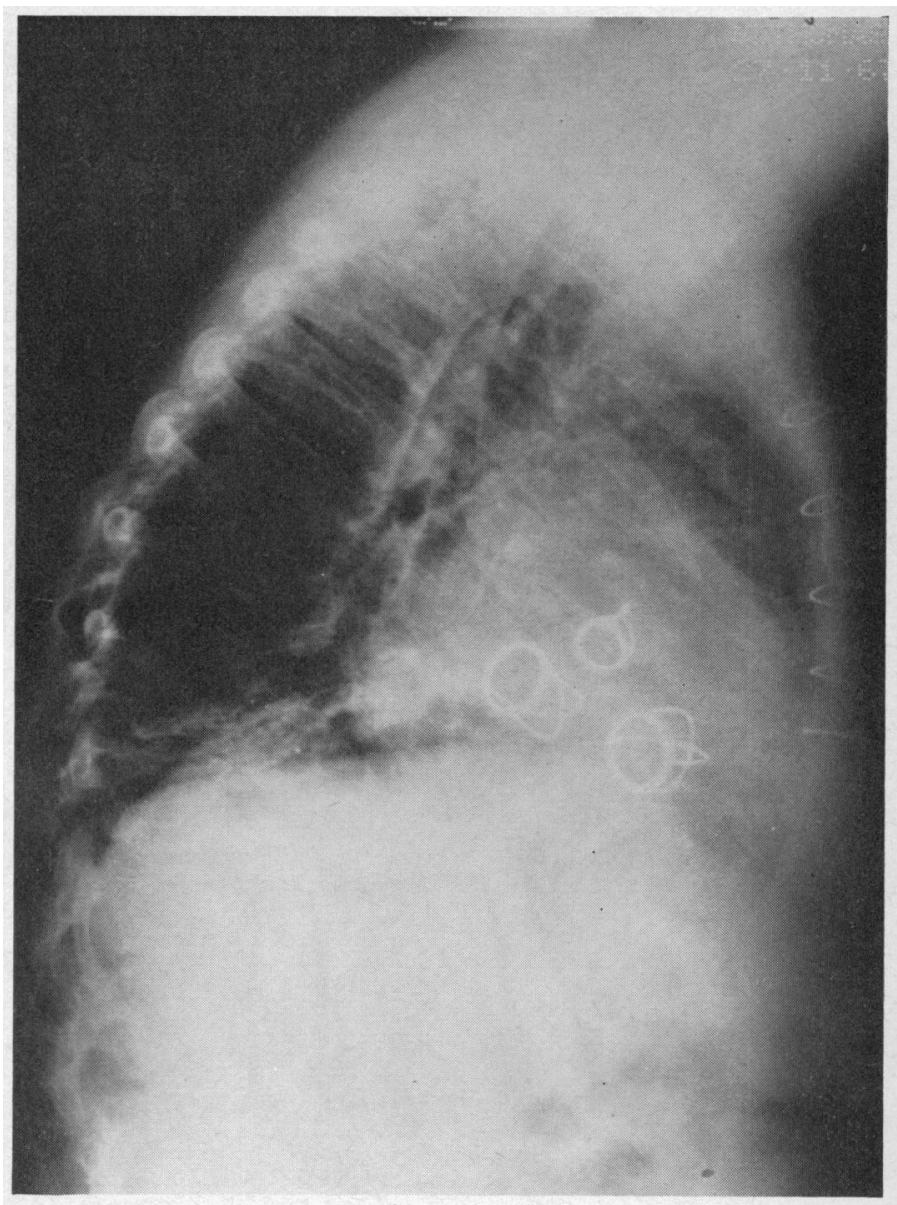

Fig. 3

FIG. 1.-Case 4. Excised valves. The aortic valve is above, the tricuspid below left, and the mitral below right. All these sets of valve cusps are fibrous, thickened, and shrivelled, and were causing marked incompetence.

Fig. 2.-Case 7. Posteroanterior chest radiograph. The three Starr valves are seen with the aortic valve above, tricuspid valve on patient's right, and mitral valve on left.

FIg. 3.-Case 7. Right lateral chest radiograph. The aortic valve is above, the mitral valve is posterior, and the tricuspid valve is anterior.

Fig. 1A and 1B.-A firm additional thrust completed the rotation manipulation. 